\title{
Publisher Correction: Spatial planning with long visual range benefits escape from visual predators in complex naturalistic environments
}

\author{
Ugurcan Mugan (iD) \& Malcolm A. Maclver (i)
}

Correction to: Nature Communications https://doi.org/10.1038/s41467-020-16102-1, published online 16 June 2020.

The original version of this Article contained an error in Ref. 4, which omitted the title of the paper in the edited volume: Yamakita, T. \& Miyashita, T. in Integrative Observations and Assessments, Ecological Research Monographs, 131-148 (eds Nakano, S.-i., Yahara, T. \& Nakashizuka, T.) (Springer Japan, Tokyo, 2014). The correct form of Ref. 4 is: Yamakita, T. \& Miyashita, T. Landscape mosaicness in the ocean: its significance for biodiversity patterns in benthic organisms and fish. in Integrative Observations and Assessments, Ecological Research Monographs, 131-148 (eds Nakano, S.-i., Yahara, T. \& Nakashizuka, T.) (Springer Japan, Tokyo, 2014). This has been corrected in the PDF and HTML versions of the Article.

Published online: 14 July 2020

\footnotetext{
(c) (i) Open Access This article is licensed under a Creative Commons Attribution 4.0 International License, which permits use, sharing, adaptation, distribution and reproduction in any medium or format, as long as you give appropriate credit to the original author(s) and the source, provide a link to the Creative Commons license, and indicate if changes were made. The images or other third party material in this article are included in the article's Creative Commons license, unless indicated otherwise in a credit line to the material. If material is not included in the article's Creative Commons license and your intended use is not permitted by statutory regulation or exceeds the permitted use, you will need to obtain permission directly from the copyright holder. To view a copy of this license, visit http://creativecommons.org/licenses/by/4.0/.
}

(C) The Author(s) 2020 